\title{
A Case of Intravenous Suicide: Sodium Hypochlorite \& Benzalkonium Chloride
}

\author{
Bir İntravenöz İntihar Olgusu: Sodyum Hipoklorit \& Benzalkonyum Klorür
}

\author{
(iD Serpil Soyudoğru' ${ }^{1}$ (D) Melike Mercan Başpınar², (D) Okcan Basat ${ }^{2}$, (D) Mustafa Çalık ${ }^{1}$ \\ 1-University of Health Science Gaziosmanpaşa Training and Research Hospital Department of Emergency Medicine. \\ 2-University of Health Science Gaziosmanpaşa Training and Research Hospital Department of Family Medicine
}

\section{ABSTRACT}

Sodium hypochlorite as a strong oxidant- bleaching agent and benzalkonium chloride as a biocide are frequently used agents for cleaning and sterilization purposes, both in health care units and at home. Despite the injection of sodium hypochlorite into the venous system has been described many times before, to our knowledge self-administration of a mixture of sodium hypochlorite and benzalkonium chloride has not been reported by a way of suicide. Our patient was a health Professional who was running a sport and beauty center. The amount of total concentration intake that patient said prepared by himself ( $400 \mathrm{ml}$ of sodium hypochlorite, $400 \mathrm{ml}$ of benzalkonium chloride, and $1000 \mathrm{ml}$ of isotonic liquid ) was unknown but it was known that $>150-200 \mathrm{~mL}$ of hypochlorite in adults is enough for systemic poisoning. The cross effects of chemicals on human tissues and organs are unpredictable, our patient was discharged by recovering all systemic damages except permanent kidney damage. This study aims to present a rare suicide poisoning event and adverse clinical sequelae.

\section{ÖZET}

Sodyum hipoklorit güçlü oksitleyici, ağartıcl, benzalkonyum klorür ise biyosit özellikli olan temizlik ve sterilizasyon amaçlı hem sağlık kuruluşlarında hem de evlerde sık kullanılan ajanlardır. Venöz sisteme sodyum hipoklorit enjeksiyonu daha önce birçok kez raporlanmış olsa da, bildiğimiz kadarı ile, intihar yöntemi olarak sodyum hipoklorit ve benzalkonyum klorür karıșımının kendi kendine uygulanması hiç bildirilmemiştir. Olgumuz spor ve güzellik merkezi işleten bir sağlık uzmanı idi. Hastanın kendi hazırladığını söylediği toplam derişimden (400 ml sodyum hipoklorit, $400 \mathrm{ml}$ benzalkonyum klorür ve $1000 \mathrm{ml}$ izotonik sivl) alım miktarı belirsizdi, ancak yetişkinlerinde > 150-200 mL hipokloritin sistemik zehirlenme için yeterli olduğu bilinmektedir. Insan doku ve organlar üzerinde kimyasalların çapraz etkileri öngörülemezken, olgumuz kalıcı böbrek hasarı dışında sistemik tüm bulguları iyileşerek taburcu olmuştur. Bu çalışmanın amacı, nadir bir intihar amaçlı zehirlenme olay ile klinik sekelini sunmaktır.
\end{abstract}

\section{Key Words:}

Benzalkonium

chloride,

Poisoning,

Suicide,

Sodium hypochlorite.

\section{Anahtar Kelimeler:}

Benzalkonium

chloride,

Zehirlenme,

Intihar,

Sodium hypochlorite

\section{INTRODUCTION}

Sodium hypochlorite is a strong oxidizing and chlorinating agent. It is not flammable, but it makes explosive hazards when it comes into contact with organic materials such as paper, wood, grease, and oil (1). Due to its antimicrobial and tissue-dissolving properties, sodium hypochlorite is also widely used by dentists to clean the root canals during endodontic treatment, too. Multiple reports document skin burns and permanent nerve injury when sodium hipoklorit contacts oral tissues. It has demonstrated esophageal edema, hemorrhage, and stricture formation following ingestion (2-5). In cases of suicide poisoning, many intravenous injection has been reported. Especially during the late 1980s, doctors advised intravenous drug users to sterilize their shared needles with a sodium hypochlorite solution (5.25\%) to reduce transmissible illnesses. (6-8)

Toxidromas or Toxicological Syndromes are clinical syndromes that can be useful to determine the etiology in cases of poisoning. However, symptoms alone may not be sufficient for diagnosis. Also, there are common poisoning symptoms for many toxic substances, as well as symptoms that vary from person to person. A definitive diagnosis should be made only with the support of laboratory findings besides toxidrome (9). In the case of oral sodium hypochlorite poisoning; the diagnosis can typically be made with a careful history, including details of the specific product used, the hypochlorite concentration, and the relevant amount. Since hypochlorite (bleach) produces a characteristic chlorine smell, this can provide a diagnostic hint. In severe cases, it appears hypersalivation, difficulty swallowing, retrosternal pain, or hematemesis due to corrosive injury (2). Although limited supporting data are provided, estimates of $>40 \mathrm{~mL}$ or $5 \mathrm{~mL} / \mathrm{kg}$ in children or $>150-200 \mathrm{~mL}$ in adults of dilute solutions have been suggested as amounts likely to cause corrosive or systemic poisoning (2)

The biocide activity of benzalkonium chloride (BAC) is based on interaction with lipids and proteins of biological membranes. Benzalkonium chloride can also be added to nasal preparations to prevent microbial contamination (10). In the production chain of minimally processes fruits and vegetables, washing with sanitizing solutions is usually, the only step by which the number of pathogenic and spoilage microorganisms can be reduced. Sanitizing with chemical, that generally 


\section{Soyudoğru et al}

Table 1: Evaluation of the laboratory test results on the emergency application

\begin{tabular}{|c|c|c|}
\hline Laboratory test & Results & Range of laboratory \\
\hline Glucose & $155 \mathrm{mg} / \mathrm{dL}$ & $74-106$ \\
\hline Leukocyte & $12.7 \quad 10^{3} / \mathrm{uL}$ & $4.10-11.0$ \\
\hline Neutrophil & $11.6410^{3} / \mathrm{uL}$ & $0.1-1.0$ \\
\hline Sodium & $146 \mathrm{mmol} / \mathrm{L}$ & $135-145$ \\
\hline Potassium & $3.9 \mathrm{mmol} / \mathrm{L}$ & $3.5-5.1$ \\
\hline Calcium & $7.70 \mathrm{mg} / \mathrm{dL}$ & $8.8-10.6$ \\
\hline Chlorine & $115 \mathrm{mmol} / \mathrm{L}$ & $101-109$ \\
\hline Blood Urea Nitrogen (BUN) & $45 \mathrm{mg} / \mathrm{dL}$ & $17-43$ \\
\hline Creatinine & $1.97 \mathrm{mg} / \mathrm{dL}$ & $0.67-1.17$ \\
\hline Albumin & $3.68 \mathrm{~g} / \mathrm{dL}$ & $3,5-5$ \\
\hline Indirect bilirubin & $1.72 \mathrm{mg} / \mathrm{dL}$ & $0-0.8$ \\
\hline Total bilirubin & $2.07 \mathrm{mg} / \mathrm{dL}$ & $0.3-1.2$ \\
\hline ALT & 18 & $0-50$ \\
\hline AST & $50 \quad \mathrm{U} / \mathrm{L}$ & $0-50$ \\
\hline Lactate dehydrogenase (LDH) & $2246 \quad \mathrm{U} / \mathrm{L}$ & $230-460$ \\
\hline C-reactive protein & $30.5 \mathrm{mg} / \mathrm{L}$ & $0-6$ \\
\hline Procalcitonin & $5.78 \quad \mathrm{ng} / \mathrm{mL}$ & $\begin{array}{l}\text { procalcitonin }<0,5 \mathrm{ng} / \mathrm{ml} \text { normal } \\
0,5-2,0 \mathrm{ng} / \mathrm{ml} \text { pozitif (sepsis?) 2,0-10,0 }\end{array}$ \\
\hline Amylase & $112 \mathrm{U} / \mathrm{L}$ & $28-100$ \\
\hline Lipase & 198 & $0-67$ \\
\hline Prothrombin Time (PT) & $>120$ second & $8.2-12$ \\
\hline D-dimer & 2600 ug/L & $80-630$ \\
\hline Troponin-I & $16.8 \mathrm{ng} / \mathrm{L}$ & $<19.8$ \\
\hline CK-MB & $2.70 \quad \mathrm{ng} / \mathrm{mL}$ & $0.6-6.3$ \\
\hline Ethanol & $3 \mathrm{mg} / \mathrm{dL}$ & $0-50$ \\
\hline $\mathrm{pH}$ & 7.30 & $7.35-7.45$ \\
\hline p02 & $54.5 \mathrm{~mm} / \mathrm{Hg}$ & $83.0-108.0$ \\
\hline pCO2 & $39.6 \mathrm{~mm} / \mathrm{Hg}$ & $32.0-48.0$ \\
\hline cHCO3 & $19.3 \mathrm{mEq} / \mathrm{L}$ & - \\
\hline
\end{tabular}

includes chlorine compounds (benzalkonium chloride, sodium hypochlorite etc.), is the primary contribution to the safety and preservation of these products (11). At the same time, dentists apply both chemicals to eliminate bacterias in dental tissues as a disinfection method, too (12). Although poisoning cases related to intake of benzalkonium chloride or sodium hypochlorite have been reported in the literature, suicide attempts both mixing sodium hypochlorite and benzalkonium chloride have not been reported before.

\section{CASE}

A 39-years-old male patient with no psychiatric or chronic disease was brought to our emergency room by syncope attack. It was learned that he was a health professional who was running a sport and beauty center. He injected in his vein for a suicide attempt by mixing 5 tea glasses $(400 \mathrm{ml})$ of zefiran (benzalkonium chloride),
5 tea glasses $(400 \mathrm{ml})$ of bleach (sodium hypochlorite) and 1000 cc of isotonic liquid. On physical examination, the general condition of the patient was poorly confused. The pupils were isochoric (3/3) and pupillary light reflex (PLR) were bilaterally positive. His Glasgow Coma Score was 9 points (Eye Opening=2, Verbal=2, Motor=5). In his biochemistry (Table 1), high values for; leukocyte, neutrophil, glucose, sodium, chlorine, urea-creatinine, C-reactive protein (CRP), amylase, lipase, indirect bilirubin, lactate dehydrogenase (LDH), protrombin time (PT), D-dimer were detected. His blood gas showed metabolic acidosis. Potassium $\left(\mathrm{K}^{+}\right)$, ALT, and AST levels were normal. Urine output was anuric. Blood pressure was 160/100 mmHg, pulse 52 / minute, S1 S2 hearth sounds were natural and ECG has shown bradyarrhythmia. The respiratory rate was $30 / \mathrm{min}$, and respiratory sounds of both lungs were decreased and common rough rales were detected. Posteroanterior 


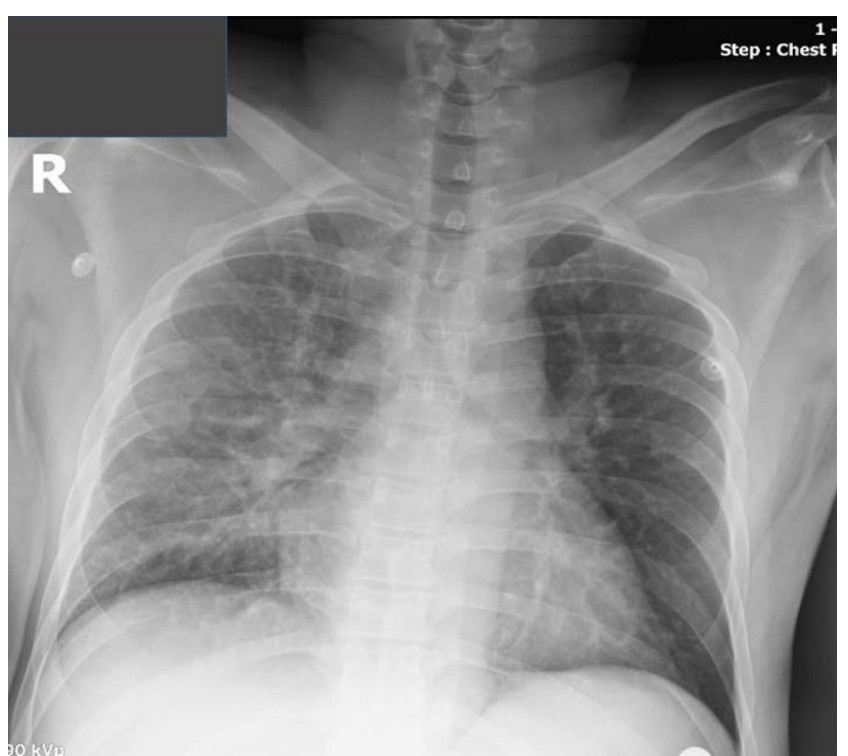

Figure 1: Posterior anterior chest X-ray image

(PA) chest view demonstrated bilateral infiltrations, more prominent in the right lung (Figure 1 ). 50\% oxygen was administered by a non-rebreather mask. The $\mathrm{pH}$ in repeated arterial blood gas: 7.32, $\mathrm{PaCO} 2: 24 \mathrm{mmHg}$, PaO2: 36 mmHg, Oxygen-free SpO2: 72\%, respiratory rate: $50 / \mathrm{min}, \mathrm{PaO} 2 / \mathrm{FiO} 2<200$. As a result of the development of acute respiratory distress syndrome, non-invasive mechanical ventilation was applied. The patient, who was consulted with the anesthesia department transferred to the external center at the 3rd level intensive care unit. A continuous venous-venous hemodiafiltration (CVVHDF) was connected to him. After 3 months of hospitalization, the patient returned to chronic renal failure and was discharged with a nephrology follow-up. The patient, who had a good general condition in the outpatient follow-up for the 6th month, did not have any complaints and continued his nephrology follow-up. As seen in Table 2, low Glomerular Filtration Rate (GFR) has become permanent.

\section{DISCUSSION}

In a study for evaluation of forensic cases applied to the emergency department by Küçük et al. the poisoning rate was found at $8.68 \%$. It was observed that $454 / 6412$ (7.1\%) of the cases aimed at self-suicide. 21/6412 $(0.3 \%)$ of cases were poisoning due to liquid agents such as ethyl alcohol, methyl alcohol, and sodium hypochlorite. $13 / 6412(0.2 \%)$ of poisoning cases were suicide with organophosphates (6).

In a case report, accidentally sodium hypochlorite mixing with hemodialysis fluid had caused widespread hemolysis, cyanosis, sudden drops in serum electrolytes, hyperkalemia, cardiac and respiratory arrest $(13,14)$. Another example was the development of acute hydrocephalus and ventriculitis that occurred as a result of self- injecting 5 cc of mixed chemical-containing toilet cleaning detergent such as sodium hypochlorite into its ventriculoperitoneal shunt reservoir for suicide attempt by the patient with a history of the bipolar disease (13).

Benzalkonium chloride is a germicide that is used as a disinfectant for cleaning surfaces and instruments, and as an antiseptic in the skin, mucous membranes, and body cavities. Sodium hypochlorite is a widely used chemical solution for household cleaning (13). BAC is also included in most medical preparations, such as nasal sprays. The siliotoxic effect of BAC is neutralized after nasal administration, and BAC-related proinflammatory effects have not been observed in vivo in healthy individuals. High doses of BAC are irritating even for people without the nasal disease. Today, the authors state that nasal preparations similar to inhalation preparations have taken a useless risk for BAC (10). Deaths have been reported due to accidental ingestion. Shortness of breath and pulmonary edema may develop as a result of inhalation exposure (2). Cases of poisoning have been reported with oral BAC intakes, for example, a case of esophagitis due to caustic burns resulting from accidental BAC (zefiran forte solution) intake by the mother instead of medication (tavegyl syrup) (15). However, the case related to BAC intake directly by vascular path has not been seen before.

On the other hand, intravenous suicide attempts are more narcotic drug-related because vascular drug users are at risk-taking behaviors related to substance use (16) but our patient had no narcotic drug history.

Table 2: Evaluation of the renal function before and after hospitalization based on the data system (GFR was calculated by Cockcroft Gault formula)

\begin{tabular}{|l|l|l|l|}
\hline Date & Plasma Creatinine level & Range of laboratory & Glomerular Filtration Rate (GFR) \\
\hline 04.02 .2020 & $1.14 \mathrm{mg} / \mathrm{dL}$ & $0.67-1.17$ & $79.06 \mathrm{~mL} / \mathrm{min}$ per $1.73 \mathrm{~m}^{2}$ \\
\hline 02.08 .2019 & $1.30 \mathrm{mg} / \mathrm{dL}$ & $0.67-1.17$ & $71.60 \mathrm{~mL} / \mathrm{min}$ per $1.73 \mathrm{~m}^{2}$ \\
\hline 09.07 .2019 & $2.70 \mathrm{mg} / \mathrm{dL}$ & $0.67-1.17$ & $34.47 \mathrm{~mL} / \mathrm{min}$ per $1.73 \mathrm{~m}^{2}$ \\
\hline 10.07 .2019 & $2.44 \mathrm{mg} / \mathrm{dL}$ & $0.67-1.17$ & $40.24 \mathrm{~mL} / \mathrm{min}$ per $1.73 \mathrm{~m}^{2}$ \\
\hline 11.06 .2019 & $1.55 \mathrm{mg} / \mathrm{dL}$ & $0.67-1.17$ & $60.05 \mathrm{~mL} / \mathrm{min}$ per $1.73 \mathrm{~m}^{2}$ \\
\hline 11.06 .2019 & $1.94 \mathrm{mg} / \mathrm{dL}$ & $0.67-1.17$ & $47.98 \mathrm{~mL} / \mathrm{min}$ per $1.73 \mathrm{~m}^{2}$ \\
\hline 17.11 .2017 & $0.90 \mathrm{mg} / \mathrm{dL}$ & $0.70-1.20$ & $103.42 \mathrm{~mL} / \mathrm{min}$ per $1.73 \mathrm{~m}^{2}$ \\
\hline
\end{tabular}




\section{Soyudoğru et al}

In literature, simultaneous poisoning with both was observed in our case for the first time. In our patient, mostly acute hemolysis findings were observed, lung and kidney functions were affected, and acute renal failure developed. He was discharged with chronic kidney failure after 3 months of hospitalization.

\section{CONCLUSION}

The risk of progression to multi-organ failure in toxic substance intake increases with dose and time. Our case would contribute to the toxicology literature with the development of chronic renal failure as a result of intravenous sodium hypochlorite and benzalkonium chloride with mixing toxicity to human tissues.

\section{Conflicts of Interest}

All other co-authors have no conflicts of interest.

\section{REFERENCES}

1. Clayton GD, Clayton FE: Patty's industrial hygiene and toxicology. Vol. 2A. Toxicology: John Wiley \& Sons, Inc., Baffins Lane, Chichester, Sussex PO19 1DU; 1981.

2. Slaughter RJ, Watts M, Vale JA, Grieve JR, Schep LJ: The clinical toxicology of sodium hypochlorite. Clinical toxicology 2019, 57(5):303-311.

3. Kleier DJ, Averbach RE, Mehdipour O: The sodium hypochlorite accident: experience of diplomates of the American Board of Endodontics. Journal of Endodontics 2008, 34(11):1346-1350.

4. Serper A, Özbek M, Çalt S: Accidental sodium hypochlorite-induced skin injury during endodontic treatment. Journal of endodontics 2004, 30(3):180-181

5. Sabala CL, Powell SE: Sodium hypochlorite injection into periapical tissues. Journal of Endodontics 1989, 15(10):490-492 Küçük E, Günel C: Demographic characteristics of forensic investigation in emergency service. Sakarya Tip Dergisi 2016, 6:100-105. Froner GA, Rutherford GW, Rokeach M: Injection of sodium hypochlorite by intravenous drug users. JAMA 1987, 258(3):325-325.

Morgan DL: Intravenous injection of household bleach. Annals of emergency medicine 1992, 21(11):1394-1395.

9. $\quad$ Akkan AG: Toksikolojik Sendromlar (Toksidromlar) ve İlaç Zehirlenmeleri-I. İÜ Cerrahpafla Tıp Fakültesi Sürekli Tıp Eğitimi Etkinlikleri Sempozyum dizisi 2002, 32:21-53.

10. Gasset AR: Benzalkonium chloride toxicity to the human cornea. American journal of ophthalmology 1977, 84(2):169-171

11. São José JFB, Vanetti MCD: Effect of ultrasound and commercial sanitizers in removing natural contaminants and Salmonella enterica Typhimurium on cherry tomatoes. Food Control 2012, 24(1-2):95-99.

12. ARSLAN İ, BAYGIN Ö: Çocuk diş hekimliğinde kullanılan kavite dezenfeksiyon yöntemleri. Atatürk Üniversitesi Diş Hekimliği Fakültesi Dergisi, 29(1):124-132.

13. Signorelli JW, Osbun JW, Arias EJ, Reynolds LC, Chyatte D, Reynolds MR: Self-injection of household cleaning detergents into a ventriculoperitoneal shunt reservoir during a suicide attempt: a case report and literature review. Acta neurochirurgica 2016, 158(9):16551660 .

14. Hoy RH: Accidental systemic exposure to sodium hypochlorite (Clorox) during hemodialysis. American journal of hospital pharmacy 1981, 38(10):1512-1514

15. Yılmaz HL: Çocukluk döneminde zehirlenme olgularına genel yaklaşım. In: Çukurova Üniversitesi Tip Fakültesi Çocuk Acil Tip Birimi http:/cat.cu.edu.tr/Egitim/\%C7OCUKLUK\%20D\%D6NEM\%DDNDE\%20ZEH\%DDRLENME\%200LGULARINA\%20GENEL\%20YAKLA\%DEIMKita.pdf.

16. Şahinkaya HH, Tekgül ZT, Özkalkanlı MY, Horsanalı B, Yeniay O: İntihar amaçlı çoklu ilaç kullanımı. Tepecik Eğit Hast Derg 2014, 3:173-176. 